\title{
ANALISIS STRUKTUR NARATIF DAN PANDANGAN MAHASISWA UNPRI TERHADAP CERITA RAKYAT NIAS
}

\author{
Ermina Waruwu, M.Th, \\ Surel: erminawaruwu@unprimdn.ac.id \\ Benediktus Benteng Kurniadi, Lic.IC \\ Surel: Gabrielsing@gmail.com \\ Universitas Prima Indonesia
}

\begin{abstract}
Absrak
Struktur naratif (Chattman) merupakan teori sastra dalam kelompok teori postrukturalisme naratologi yang terdiri atas Struktur plot, Struktur fisik, ras, dan relasi gender, Struktur ruang dan waktu serta Struktur transmisi narasi. Teori struktural ini banyak dimanfaatkan bagi pengkaji sastra lisan yang berhubungan dengan cerita rakyat. Cerita rakyat adalah salah satu kekayaan budaya yang dimiliki oleh bangsa Indonesia. Setiap daerah dapat dipastikan memiliki cerita rakyat termasuk cerita rakyat suku Nias. Penelitian ini bertujuan untuk mengeksplorasi dan menganalisis strukturstruktur cerita Rakyat Nias dan pandangan mahasiswa suku Nias terhadap cerita Rakyat. Subyek penelitian ialah mahasiswa-mahasiswa suku Nias yang ada di kampus Universitas Prima Indonesia yang terdiri atas 14 orang yang dipilih secara purposive sampling. Teknik pengumpulan data ialah kuesioner dengan daftar tanya sebagai instrumen. Teori yang digunakan dalam menganalisis data ialah teori struktur naratif dan teori deskriptif kualitatif. Metode analisis menggunakan teori Milles dan Hubberman yakni reduksi data, penyajian data dan penarikan kesimpulan. Berdasarkan analisis data telah diperoleh hasil penelitian yakni struktur cerita rakyat Nias memiliki struktur plot, struktur fisik, ras, dan relasi gender, struktur ruang dan waktu serta struktur transmisi narasi yang terjalin menjadi satu kesatuan yang logis dan sistematis. Mahasiswa UNPRI menyatakan pandanganya terhadap cerita rakyat Nias yakni Mahasiswa UNPRI mengenal cerita rakyat sejak kecil, diperoleh dari orang tua dan bermanfaat karena mengandung nilai-nilai seperti nilai moral, sosial, etika dan nilai religius. Oleh sebab itu, penting adanya upaya pelestarian dan pengembangan cerita rakyat oleh semua pihak agar tetap melestarikan cerita rakyat Nias tersebut dan menjadikannya sebagai kekayaan budaya daerah dan budaya nasional.
\end{abstract}

Kata Kunci: Struktur Naratif, Mahasiswa UNPRI dan Cerita Rakyat Nias

\section{PENDAHULUAN}

Strukturalisme pada dasarnya merupakan cara berpikir tentang dunia terutama yang berhubungan dengan tanggapan dan deskripsi struktur-struktur. Struktur yaitu suatu sistem transformasi yang bercirikan keseluruhan, dan keseluruhan itu dikuasai oleh hukum-hukum (rule of composition) tertentu dan mempertahankan atau bahkan 
memperkaya dirinya sendiri karena cara dijalankannya transformasi-transformasi itu tidak memasukkan unsur-unsur dari luar. Faruk (2012:173) memberi definisi strukturalisme adalah sebuah paham, sebuah keyakinan bahwa segala sesuatu yang ada dalam dunia ini mempunyai struktur atau bekerja secara struktural. Strukturalisme pada dasarnya sebuah cara berpikir tentang dunia yang terutama mengikatkan diri pada persepsi dan deskripsi mengenai struktur tersebut.

Sejalan dengan apa yang dijelaskan oleh Faruk, Suwardi Endraswara juga memberi penjelasan tentang strukturalisme (2011:49) yaitu dalam pandangan karya sastra diasumsikan sebagai fenomena yang memiliki struktur yang saling terkait satu sama lain. Kodrat struktur itu akan bermakna apabila dihubungkan dengan struktur lain. Struktur tersebut memiliki bagian yang kompleks, sehingga pemaknaan harus diarahkan ke dalam hubungan antar unsur secara keseluruhan. Keseluruhan akan lebih berarti dibanding bagian atau fragmen struktur. Strukturalisme sebenarnya merupakan paham filsafat yang memandang dunia sebagai realitas berstruktur. Dunia sebagai suatu hal yang tertib, sebagai sebuah relasi dan keharusan. Jaringan relasi ini merupakan struktur yang bersifat otonom. Karena keteraturan struktur itu, akan membentuk sebuah sistem yang baku dalam penelitian sastra. Yang menganalisis struktur karya sastra adalah LeviStrauss dan Propp. Levi-Strauss dan Propp yang mencoba menganalisis struktur mitos (cerita rakyat), sebab strukturalisme mampu menggambarkan pemikiran pemilik cerita.

Suwardi Endraswara (2011:50) menjelaskan strukturalisme merupakan cabang penelitian sastra yang tak bisa lepas dari aspek-aspek linguistik. Sejak zaman Yunani, Aristoteles telah mengenalkan strukturalisme dengan konsep adalah Wholeness, unity, complexity. Hal ini merepresentasikan bahwa keutuhan makna bergantung pada koherensi keseluruhan unsur sastra. Keseluruhan sangat berharga dibandingkan unsur yang berdiri sendiri. Karena masing-masing unsur memiliki pertautan yang membentuk sistem makna. Setiap unit struktur teks sastra hanya akan bermakna jika dikaitkan hubungannya dengan struktur lainnya. Hubungan tersebut dapat berupa pararelisme, pertentangan, inverse, dan kesetaraan. Yang terpenting adalah bagaimana fungsi hubungan tersebut menghadirkan makna secara keseluruhan. Sebagai contoh, kata manis baru bermakna lengkap ketika dipertentangkan dengan kata pahit. Ini berarti bahwa struktur sastra memiliki fungsi.

Teori struktur naratif merupakan teori sastra dalam kelompok teori postrukturalisme naratologi. Ratna (2015:252-290) mengelompokkan Seymour Chatman bersama Genette, Prince, Culler, Barthes, Bakhtin, Hayden, Pratt, Lacan, Foucault, 
Lyotard, dan Baudrilard sebagai tokoh-tokoh postrukturalisme naratologi. Di dalam hal ini, Chatman (1986:140) menyatakan bahwa gagasan tentang pesan narasi mengandaikan konsep pengirim: “,Sender" is logically implicated by „,message;" a sender is by definition built-in: inscribed or immanent in every message." (Pengirim secara logis terlibat dengan 'pesan'; pengirim tertulis atau imanen dalam setiap pesan.) Sejalan dengan perkembangan teori struktur naratif, Ratna (2015:251) menempatkan teori ini sebagai teori postrukturalisme, "Postrukturalisme memandang betapa pentingnya sejarah dan waktu dalam mempermasalahkan bahasa dalam penggunaannya." Di sinilah Seymour Chatman, profesor retorika di University of California, Berkeley merumuskan teori struktur naratif dalam kajian fiksi dan film. Diagram teori struktur naratif Seymour Chatman menempatkan narasi sebagai cerita (story) dan wacana (discourse).

Oleh karena itu, teori struktural dapat dimanfaatkan untuk penelitian folklor pada umumnya. Hampir setiap genre folklor memiliki struktur tertentu. Tiap struktur terkait dengan makna secara keseluruhan. Teori struktural ini banyak dimanfaatkan bagi pengkaji sastra lisan yang berhubungan dengan cerita rakyat. Aspek-aspek fiksi dan fantasi dalam prosa rakyat tersebut menjadi inti kajian. Kajian ditekankan pada unsurunsur pembangun sebuah teks. Berarti pula bahwa analisis sastra lisan memandang budaya sebagai teks.

Berdasarkan penjelasan di atas, struktur naratif cerita rakyat Nias yang akan dideskripsikan dan dianalisis terdiri dari empat komponen. Keempat komponen tersebut adalah 1) Struktur plot, yakni struktur narasi cerita rakyat Nias yang didasarkan pada tindakan dan kejadian yang muncul dari orang, benda, dan berbagai substansi isi cerita. Struktur plot sebagai sebuah penceritaan pada hakikatnya terbagi atas tiga bagian, yaitu bagian permulaan, pertengahan, dan bagian akhir suatu cerita. Struktur plot ini akan menentukan apakah cerita beralur maju atau beralur mundur. Menurut Chatman (1980:85), "Aristotle distinguished between fortunate and fatal plots, according to whether the protagonist"s situation improved or declined." (Aristoteles membedakan antara alur yang fatal dan keberuntungan menurut apakah situasi protagonis meningkat atau menurun). Dengan demikian, pendeskripsian struktur plot tersebut dapat memperlihatkan protagonis yang sangat baik, tidak begitu jahat, atau luar biasa baiknya, 2) Struktur fisik, ras, dan relasi gender, yakni struktur narasi cerita rakyat Nias yang mengungkapkan karakter pelaku cerita. Struktur relasi gender merupakan istilah yang mengacu kepada analisis penokohan dan karakteristik. Analisis ini lebih menekankan kepada hubungan antar tokoh laki-laki dengan perempuan. 
Hubungan tersebut ditentukan oleh tindakan nyata tokoh cerita, baik dalam pemunculan maupun peniruannya. 3) Struktur ruang dan waktu, yakni struktur narasi cerita rakyat yang didasarkan pada latar tempat dan waktu tindakan serta kejadian berlangsung. Chatman (1980:152) memberi perbedaan ruang dan waktu sebagai berikut, "As the dimension of story-evens is time, that of story-existence is space." (Seperti dimensi kejadian-cerita adalah waktu, maka dimensi eksistensi- cerita adalah ruang). Dengan kata lain, struktur ruang ditentukan oleh tempat berpijak cerita sedangkan struktur waktu ditentukan oleh pemunculan kejadian dalam cerita yang bersangkutan, 4) Struktur transmisi narasi, yakni struktur pengiriman narasi yang akan mengungkapkan sudut pandang narator dalam menyampaikan isi cerita. Secara runtut A. Teeuw (2015:129-131) memaparkan bagaimana para Formalis mengembangkan karya sastra sehingga cepat berkembang ke arah strukturalis. Karya sastra sebagai struktur menjadi sasaran utama dalam ilmu sastra. Tiap struktur terkait dengan makna secara keseluruhan. Teori struktural ini banyak dimanfaatkan bagi pengkaji sastra lisan yang berhubungan dengan cerita rakyat.

Cerita rakyat adalah salah satu kekayaan budaya yang dimiliki oleh bangsa Indonesia. Setiap daerah dapat dipastikan memiliki cerita rakyat. Cerita rakyat termasuk dalam sastra tradisional. Cerita rakyat merupakan lukisan perjuangan hidup dan pengalaman masyarakat lama. Cerita rakyat adalah suatu cerita yang pada dasarnya disampaikan oleh seseorang pada orang lain melalui penuturan lisan. Cerita rakyat memiliki ciri-ciri dan fungsi. Ciri-ciri dan fungsi cerita rakyat dapat menambah khazanah atau kekayaan cerita rakyat tersebut. Isi cipta sastra yang bersifat fantastis, istana sentries, dan didaktis. Adapun sifat didaktisnya tampil karena ceritanya berusaha menggurui dan menanamkan nilai-nilai pendidikan pada penikmatnya. La Ode Gusal (2015: tanpa halaman) menjelaskan ciri-ciri dan fungsi-fungsi cerita rakyat, Pertama: ciri-cirinya yakni a) Bahasanya banyak menggunakan bahasa klise sebagai variasinya. Sering pula setiap cerita diawali dengan kata-kata seperti, konon, khabarnya, pada zaman dahulu kala dan lain-lain, b) Nama-nama pengarang sering tidak disebutkan, sehingga hasil sastranya kebanyakan anonim. Hal ini terjadi karena masyarakat lama cenderung bersifat kolektif, tidak muncul secara individual. Kedua: fungsi cerita rakyat yakni a) Sebagai penyalur ketegangan yang ada pada masyarakat, b) Sebagai protes sosial atau kendali masyarakat c) Sebagai pengesahan pranata dan lembaga kebudayaan, d) Sebagai media hiburan, e) Sebagai alat pendidikan, f) Cerita rakyat menceminkan angan angan suatu kelompok, g) Cerita rakyat dapat digunakan sebagai alat pengesahan atau penguatan suatu adat kebiasaan kelompok, h) Cerita rakyat 
berfungsi sebagai alat pendidikan budi pekerti atau tuntunan hidup, i) Cerita rakyat berfungsi sebagai alat pengendalian social (Sosial Control).

Penelitian ini difokuskan pada Cerita Rakyat (Amaedola Nidunö-dunö atau Gego) Nias. Cerita rakyat ini biasanya disampaikan secara lisan atau dituturkan secara lisan atau dengan bahasa lisan. Cerita rakyat sebagai salah satu karya sastra semakin menarik karena memiliki struktur-struktur yang saling terkait dan menjadi satu kesatuan yang tersusun secara sistematis. Inilah yang membuat cerita rakyat menarik. Teori struktural ini banyak dimanfaatkan bagi pengkaji sastra lisan yang berhubungan dengan cerita rakyat.

Namun, kita perlu bertanya, bagaimana eksistensi cerita rakyat Nias pada masa kini? Cerita rakyat di Nias pada masa kini gaungnya hampir kurang terdengar lagi. Atau boleh dikatakan cerita rakyat sebagai kekayaan sastra lisan di Nias sudah mulai perlahan-lahan menghilang, tenggelam di telan waktu. Tenggelam karena berbagai faktor permasalahan-permasalahan yang sangat kompleks. Faktor-faktor ini dapat diprediksikan karena beberapa hal, Pertama: perkembangan teknologi modern. Misalnya, anak-anak atau generasi muda lebih memilih pergi ke warnet untuk bermain game. Lebih menyukai bahan-bahan atau interaksi di media sosial seperti Facebook, Instagram, dan sebagainya yang belum tentu memberikan informasi nilai sebagai sarana dan pembentukan karakter. Kedua: apabila zaman dahalu para orangtua sering menuturkan cerita rakyat kepada anak-anaknya, sekarang mulai tidak lagi. Mungkin orang tua zaman sekarang lebih sibuk dengan pekerjaan sehingga tidak sempat menuturkan cerita rakyat, ketika pulang dari pekerjaan langsung istirahat. Ketiga: para pengajar di sekolah kurang menggunakan cerita rakyat sebagai bahan pendukung dalam proses pembelajaran. Keempat : minimnya tempat pembinaan atau wadah warisan budaya di setiap daerah ataupun di lingkungan masyarakat. Kelima: Kurangnya dialogkomunikasi di antara pemerintahan setempat, khususnya Satuan Kerja Pemerintahan daerah (SKPD) Pariwisata sebagai stakeholder untuk bekerja sama dengan tokoh-tokoh adat. Maka kepada generasi muda perlu diperkenalkan kekayaan kebudayaan tradisional yang dimiliki oleh daerahnya.

Generasi muda seperti yang diuraikan di atas termasuk mahasiswa suku Nias yang telah dan sedang belajar ilmu Teori Sastra di program pendidikan Bahasa dan Sastra Indonesia FKIP-UNPRI. Permasalahan di atas menjadi terbukti bahwa generasi muda suku Nias masa kini mulai tidak mengenal cerita rakyat Nias. Berdasarkan wawancara peneliti, tanggal 12 dan 13 Oktober 2018 kepada 8 (delapan) orang 
mahasiswa semester 1 terdiri dari 5 orang dan semester 3 terdiri dari 3 orang ditemukan bahwa 7 (tujuh) orang yang tidak mampu menyebutkan atau tidak mengenal cerita rakyat dan 1 (satu) orang saja yang mengenal dan mampu menceritakan kembali salah satu cerita rakyat Nias yakni "Laowö Maru". Atas masalah tersebut penelitian ini penting mengingat mahasiswa suku Nias sebagai calon pengajar dan pendidik tentang kekayaan sastra di kemudian hari.

Berdasarkan uraian di atas, penelitian ini bertujuan untuk membongkar kekayaan sastra lisan Nias secara umum dan secara khusus membongkar berbagai kekayaan cerita rakyat yang dimiliki masyarakat di daerah Nias. Penelitian ini akan menganalisis sekaligus memaparkan secara mendalam hasil kajian cerita rakyat Nias dengan menggunakan model teori strukturalisme. Kemudian, peneliti akan menganalisis pandangan generasi muda terhadap cerita rakyat Nias. Atas alasan ini, peneliti tertarik dan termotivasi melakukan penelitian tentang Analisis Struktur Naratif Dan Pandangan Mahasiswa Unpri Terhadap Cerita Rakyat Nias

\section{METODE PENELITIAN}

Penelitian ini menggunakan paradigma kualitatif dengan pendekatan metode strukturalisme. Peter K Manning dan Betsy Cullum Swan (Norman K. Denzim, Yvonna S. Lincoln, 2009: 619) menjelaskan bahwa strukturalisme memandang dokumen sebagai teks. Teks merupakan fenomena analitis yang dihasilkan dari berbagai definisi dan operasi teoretis. Strukturalisme berupaya untuk memetakan dan memaknai setiap elemen pada satu kesatuan dengan jalan sistematis. Suwardi Endraswara (2011:51-52) menjelaskan bahwa penekanan strukturalis adalah memandang karya sastra sebagai teks mandiri. Tirto Suwondo (2001:56) dalam buku Metodologi Penelitian sastra milik Endaswara, menyatakan bahwa Jelas, yang menjadi pijakan utama analisis adalah karya (teks sastra) itu sendiri.

Penelitian tentang struktur naratif dan pandangan mahasiswa Prodi. Bahasa dan Sastra Indonesia-FKIP-Universitas Prima Indonesia Terhadap Cerita Rakyat Nias dimulai 15 Des 2018 s/d 15 Feb 2019, berlokasi di Sekip-Kota Medan, Kampus FKIPUniversitas Prima Indonesia (UNPRI). Peneliti menetapkan informan dengan teknik purposif (M. Djunaidi dan Fauzan A., 2012:88) dimana informan memiliki kemampuan untuk memasok informasi selengkap mungkin kepada peneliti. Informan dalam penelitian ini, yaitu: mahasiswa-mahasiswa Nias yang berjumlah 14 (Empat belas) orang di program studi pendidikan Bahasa dan Sastra Indonesia-FKIP. Sumber 
data penelitian ini terdiri atas data primer yakni cerita rakyat yang dituliskan (teks) oleh subyek penelitian dan pandangan subyek penelitian terhadap keberadaan cerita rakyat Nias yang dikumpulkan melalui penyebaran angket atau quesioner (Noeng Muhadjir, 2011: 349) yang disebarkan kepada mahasiswa-mahasiswa Nias di program studi Pendidikan Bahasa dan Sastra-FKIP-UNPRI. Analisis Data menggunakan teori Milles dan Haberman (M. Djunaidi Ghony, Fauzan Almanshur, 306-312: 2012) yakni melakukan reduksi data reduksi data, penyajian data dan pengambilan kesimpulan. Teks cerita rakyat Nias yang diperoleh dari informan akan dianalisis dengan menggunakan model strukur naratif menurut teori Chatman sedangkan pandangan mahasiswa UNPRI terhadap cerita rakyat Nias dianalis dengan menggunakan teori deskriptif kualitatif. Untuk menetapkan keabsahan (trustworthiness) data diperlukan teknik pemeriksanaan (Lexy J. Moleong, 2009:326-342), yaitu peneliti menggunakan kriteria-kriteria yakni trianggulasi, menganalisis kasus negati dan melakukan proses auditing.

\section{HASIL PENELITIAN DAN PEMBAHASAN}

Cerita rakyat Nias memiliki struktur-struktur yang sistematis, rasional dan peristiwa cerita dapat dipahami dengan baik. Berikut ini peneliti memaparkan strukturstruktur cerita rakyat Nias yang berjumlah 14 (empat belas). Seluruh cerita rakyat ini diperoleh dari informan yakni mahasiswa Universitas Prima Indonesia, Medan. Berdasarkan hasil analisis data penelitian struktur naratif cerita rakyat Nias dapat diuraikan secara singkat yang terdiri atas empat bagian, antara lain:

a) Struktur Plot. Struktur plot, yakni struktur narasi cerita rakyat Nias yang didasarkan pada tindakan dan kejadian yang muncul dari orang, benda, dan berbagai substansi isi cerita. Struktur Plot ke-14 (empat belas) cerita rakyat Nias ialah Plot maju. Dikatakan plot maju karena peristiwa-peristiwa dalam cerita itu berurutan, baik berurutan waktu maupun berurutan kejadiannya. Ditemukan dari alur cerita yang disampaikan cerita rakyat Nias dimulai dengan pengawalan pengenalan para tokoh, kemudian timbulnya permasalahan atau konflik dan di akhiri dengan tahap penyelesaian masalah. Dengan kata lain, Plot sebagai "struktur gerak atau laku dalam suatu fiksi atau drama. Setiap fiksi atau karya sastra haruslah bergerak dari suatu permulaan, melalui suatu pertengahan, menuju suatu akhir, atau dengan istilah lain dari suatu eksposisi, melalui komplikasi menuju resolusi. 
b) Struktur Fisik, Ras dan Relasi Gender. Penokohan atau karakterisasi adalah proses yang dipergunakan oleh seseorang pengarang untuk menciptakan tokoh-tokoh fiksinya. Tokoh fiksi dilihat sebagai yang berada pada suatu masa dan tempat tertentu dan haruslah pula diberi motif-motif yang masuk akal bagi segala sesuatu yang dilakukannya. Tugas pengarang ialah membuat tokoh itu sebaik mungkin, seperti yang benar-benar ada. Cara untuk mencapai tujuan ini tentu beraneka ragama, termasuk pemerian atau analisis, apa yang dikatakan atau apa yang dilakukan oleh para tokoh, cara mereka beraksi dalam situasi-situasi tertentu, apa yang dikatakan oleh tokoh lain terhadap mereka atau bagaimana mereka bereaksi terhadapnya. Berdasarkan ke-14 (empat belas) cerita rakyat Nias, struktur fisik tokoh tergambar berdasarkan tokoh protagonis dan antagonis. Ditemukan bahwa ada tokoh protagonis adalah tokoh yang mendukung cerita. Dalam cerita rakyat Nias ada satu atau dua figur tokoh protagonis utama dan dibantu tokoh lain yang terlibat dalam cerita rakyat Nias. Tokoh Protagonis berwatak baik, dan menjadi idola pembaca/pendengar. Selain itu ditemukan juga ada tokoh antagonis adalah tokoh yang menjadi penentang cerita. Biasanya ada satu,dua atau lebih figur tokoh yang menentang cerita. Tokoh jenis ini berwatak jahat dan dibenci oleh pembaca dan pendengar. Penokohan protagonis dan antagonis dilakonkan oleh tokohtokoh laki-laki maupun perempuan. Relasi akhir yang yang terjadi berdasarkan peristiwa cerita bisa saja baik dan buruk Namun, peneliti menemukan kasus-kasus negatif terkait temuan penelitian tentang para tokoh dalam cerita. Ada tokoh yang menurut analisis data kurang berkaitan, antara lain:Menurut data cerita rakyat "Legenda Mado-mado Nias, anak-anak Sirao sebagai leluhur masyarakat Nias adalah 9 (sembilan) terdiri atas Luo Wemðna, Hia, Gðzð, Daeli, Hulu, Lature Danð, Tuha Zangarðfa, Lakindrðlai (Mbela/Bela), Situsð’ð Kara. Sementara, berdasarkan data cerita rakyat "Lauwðmaru", salah satu nama Sirao ialah Lahari, anaknya bernama Lauwðmaru. Dua cerita ini saling bertentangan tentang cerita para tokoh dalam cerita rakyat. Oleh karena itu, temuan ini perlu ditelusuri lebih lanjut agar para tokoh dalam cerita rakyat memiliki tingkat keterhubungan satu-sama lain.

c) Struktur Ruang dan Waktu. Latar atau setting adalah lingkungan fisik tempat kegiatan berlangsung. Dalam pengertian yang lebih luas, latar mencakup tempat dalam waktu dan kondisi-kondisi psikologis dari semua yang terlibat dalam kegiatan itu. Latar sering kali sangat penting dalam memberi sugesti akan ciri-ciri tokoh dan dalam menciptakan suasana sesuatu karya sastra.Sehubungan dengan uraian di atas, cerita rakyat Nias memiliki latar ruang atau tempat-tempat. Struktur ruang (tempat) terjadinya peristiwa dalam cerita rakyat nias antara lain: Teheholia ana'a, Lapangangan istana, Tanah Nias (pulau Nias), Sungai (Oyo dan Susua), Di atas pohon (Pohon Ara, pohon kelapa, pohon E’oyo, dsb), tanah berbatu-batu (tanah laraga), laut, pantai, kapal, 
Lðlðmatua (Nias selatan), pegunungan/perbukitan Lðlðmatua, Bðrðnadu (Nias Selatan), Hutan, Desa Fodo (Gunungsitoli). Sedangkan waktu kejadian cerita berlangsung pagi, siang, sore dan malam hari. Tokoh-tokoh dalam cerita rakyat melakukan semua aktivitas dan sistem hidup baik pagi, siang, sore dan malam hari. Namun, peneliti menemukan kasus negatif berdasarkan aspek waktu pengisahan cerita yakni dari ke 14 cerita rakyat ada 5 (lima) cerita rakyat yang belum melukiskan struktur waktu. Cerita rakyat yang tidak memiliki struktur waktu ada 5 (lima) cerita rakyat Nias antara lain: Famolaya, Siraso, Dewi Bibit Suku Nias, Legenda Awuwukha yang Perkasa, Burung Tua dan Burung Muda, Tumbal Yang Menjadi batu. Struktur waktu sangat penting dalam anasir karya sastra karena saling berhubungan dengan tempat kejadian. Dengan kata lain, struktur ruang ditentukan oleh tempat berpijak cerita sedangkan struktur waktu ditentukan oleh pemunculan kejadian dalam cerita yang bersangkutan.

d) Struktur Transmisi Narasi. Cerita rakyat Nias yang terdiri atas 14 (Empat belas) cerita rakyat ditemukan mempunya struktur transmisi narasi. Struktur pengiriman narasi yang akan mengungkapkan sudut pandang narator dalam menyampaikan isi cerita. Berdasarkan hasil analisis data struktur transmisi narasi ke-14 cerita rakyat nias beragam, antara lain: Pertama: Sudut pandang orang ketiga maha tau terdiri atas 5 (lima cerita rakyat) yakni Legenda Mado-Mado Nias", Raja Yang Beristeri Dua, Siraso, Dewi Bibit Suku Nias, Eu Böwö, Futi Lölö Nafo. Sudut pandangan orang ketiga yang serba tahu (third person omniscient point of view). Artinya sang narator, tidak mempergunakan kata ganti diri saya atau aku dalam penyajiannya bahannya benar-benar mengetahui segala sesuatu yang pantas diketahui mengenai segala tokohnya dan segala keadaan gerak tindakan atau emosi yang terlibat di dalamnya. Narator merupakan seorang pengamat yang serba tahu danbebas untuk menjelaskan motivasi-motivasi dari semua tokoh. Kedua: Sudut pandang orang ketiga jamak, terdiri atas 3 (tiga) cerita rakyat yakni Baewa Si Faero, 7 Anak Yang Dibuang, Sazuzudanö. Narator menuturkan cerita berdasarkan persepsi atau kaca mata kolketif. Narator, pengarang menyebut para tokohnya dengan menggunakan kata ganti orang ketiga jamak yakni “mereka”.Ketiga: Sudut pandang campuran terdiri atas 4 (empat) cerita rakyat yakni Anak Zamagawaulu dan aza-Gaza, Burung Tua dan Burung Muda, Lauwömaru, Tumbal Yang Menjadi batu. dalam cerita rakyat ini, narator atau pengarang menempatkan dirinya secara bergantian dari satu tokoh ke tokoh lainnya dengan sudut pandang yang berbeda-beda, misalnya, aku, kamu, kami, mereka, dia. Keempat: Sudut pandangan orang ketiga terbatas terdiri atas 1 (satu) cerita rakyat antara lain Legenda Awuwukha yang Perkasa. Sudut pandangan yang ketiga terbatas (limited third person point of view). Artinya sang persona tidak menggunakan kata ganti diri saya atau $a k u$, tetapi sebagai penggantinya 
menceritakan cerita terutama sekali sebagai satu atau dua tokoh utama yang dapat mengetahuinya. Sang persona secara tegas membatasi dirinya terhadap apa-apa yang telah dapat diketahui oleh para tokoh tersebut, apa yang telah dipikirkan atau yang dilakukannya. Kelima: Sudut pandang orang ketiga obyektif terdiri atas 1 (satu) yakni famolaya. Sudut pandang yang digunakan oleh narator ialah melukiskan semua tindakan tokoh dalam cerita namun tak mengungkapkan apa yang dipikirkan serta dirasakan oleh tokoh-tokoh cerita. Secara ringkas struktur naratif cerita rakyat Nias berdasarkan hasil analisis dari teori Chattman dapat dilihat pada tabel berikut ini.

\section{Tabel}

Struktur Cerita rakyat Nias

\begin{tabular}{|c|c|c|}
\hline No & $\begin{array}{l}\text { Struktur Cerita } \\
\text { Rakyat Nias }\end{array}$ & Keterangan \\
\hline 1 & Struktur Plot & Maju (Progresif) \\
\hline 2 & $\begin{array}{lr}\text { Struktur } & \text { Fisik, } \\
\text { Ras dan Relasi } \\
\text { Gender }\end{array}$ & $\begin{array}{l}\text { - } \begin{array}{l}\text { Watak tokoh yang protagonis dan antagonis dan } \\
\text { - }\end{array} \text { Tokoh laki-laki dan perempuan } \\
\text { - } \quad \text { Tokoh-tokoh fabel yang berlaku seperti manusia }\end{array}$ \\
\hline 3 & $\begin{array}{l}\text { Struktur Ruang } \\
\text { dan Waktu }\end{array}$ & $\begin{array}{l}\text { - Struktur Ruang: } \\
\text { Teheholia ana'a, Lapangangan istana, Tanah } \\
\text { Nias (pulau Nias), Sungai (Oyo dan Susua), Di } \\
\text { atas pohon (Pohon Ara, pohon kelapa, pohon } \\
\text { E’oyo, dsb), tanah berbatu-batu (tanah laraga), } \\
\text { laut, pantai, kapal, Lðlðmatua (Nias selatan), } \\
\text { pegunungan/perbukitan Lðlðmatua, Bðrðnadu } \\
\text { (Nias Selatan), Hutan, Desa Fodo } \\
\text { (Gunungsitoli) } \\
\text { Struktur Waktu } \\
\text { Pagi, Siang, Sore dan Malam hari }\end{array}$ \\
\hline 4 & $\begin{array}{l}\text { Struktur } \\
\text { Transmisi Narasi }\end{array}$ & 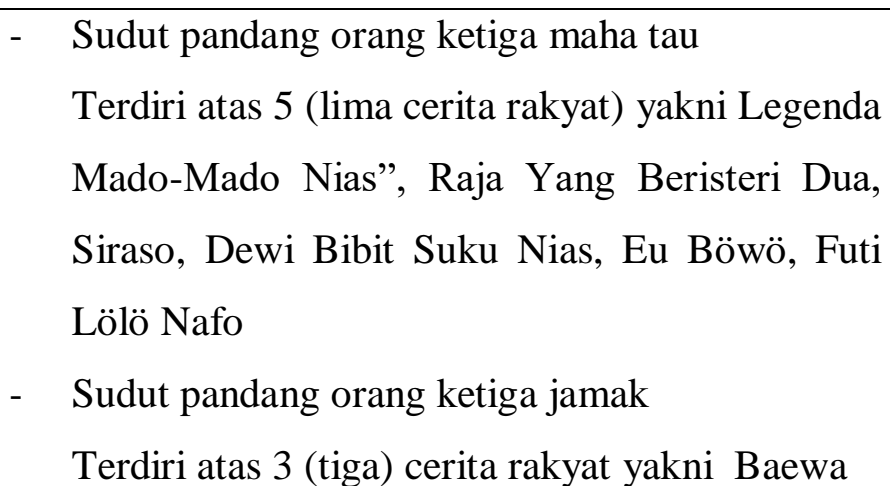 \\
\hline
\end{tabular}




\begin{tabular}{|l|l|}
\hline & Si Faero, 7 Anak Yang Dibuang, Sazuzudanö \\
- & Sudut pandang campuran \\
Terdiri atas 4 (empat) cerita rakyat yakni Anak \\
Zamagawaulu dan aza-Gaza, Burung Tua dan \\
Burung Muda, Lauwömaru, Tumbal Yang \\
Menjadi batu \\
Sudut pandangan orang ketiga terbatas \\
Terdiri atas 1 (satu) cerita rakyat antara lain \\
Legenda Awuwukha yang Perkasa \\
Sudut pandang orang ketiga obyektif \\
Terdiri atas 1 (satu) yakni famolaya
\end{tabular}

Berkaitan dengan analisis struktur cerita rakyat di atas, mahasiswa UNPRI juga memberikan pandandangannya tentang cerita rakayat yakni mahasiswa UNPRI mengenal cerita rakyat sejak kecil dan diperoleh dari orang tua mereka sendiri. Namun, keberadaan cerita rakyat saat ini "Terancam Punah" karena berbagai alasan 1) keluarga tidak mengingat lagi cerita rakyat, 2) Cerita rakyat nias jarang sekali dituturkan oleh orang tua ataupun masyarakat, 3) Kisah cerita rakyat tidak terdengar lagi, 4) Tidak ada satu pun orang yang meneruskan cerita itu, maupun dituturkan diberbagai kegiatan yang ada di masyarakat, 5) Tidak ada satu orang pun yang meneruskan/mewariskan cerita itu secara turun-temurun apalagi dituturkan diberbagai kegiatan yang ada di lingkungan yaitu, masyarakat, sekolah, 6) Cerita rakyat Nias jarang didengar, 7) Cerita rakyat Nias sudah jarang diketahui oleh masyarakat Nias dan mulai tidak terdengar lagi, 8) Cerita rakyat belum diperkenalkan/dituturkan oleh siapapun.

Kemudian, mahasiswa UNPRI mengatakan bahwa cerita rakyat Nias "bermanfaat" karena 1) Ada Pengetahuan asal usul orang Nias dan asal usul marga-marga Nias dari dimensi mitologi, 2) Mengajarkan nilai-nilai 3) mengajarkan budaya perkawinan Nias, 4) Menjadi pengajaran bagi masyarakat agar jangan melakukan balas dendam seperti membunuh, 5) mengandung makna pendikan kehidupan rukun keluarga, 6) mengandung unsur pelajaran menarik yaitu kebaikan sesungguhnya ialah mampu menerima kejahatan dari orang lain, 7) Memberikan pelajaran tentang tindakan-tindakan kebaikan dan tidak balas dendam.

Selanjutnya, mahasiswa UNPRI memiliki pandangan bahwa nilai-nilai yang ada dalam cerita rakyat Nias yaitu nilai moral, sosial, etika, nilai agama (religius). Mahasiswa 
UNPRI juga memandang bahwa waktu penceriteraan cerita rakyat dilakukan 1) pada zaman dahulu , 2) kapan dan dimanapun, 3) saat "dewasa", 4) diceritakan saat kecil, 5) saat perlombaan sekolah.

Selain itu, Cerita rakyat Nias dapat menjadi atau berfungsi sebagai "Tuntunan/Pendidikan. Karena alasan fungsi ini maka perlu upaya pelestarian dan pengembangan Cerita Rakyat Nias yang dilakukan dengan cara "Di pertunjukan/di pentaskan/ di tuturkan dengan berbagai cara” dan Yang melakukan upaya pelestarian dan pengembangan cerita rakyat ialah "masyarakat. Terakhir, mahasiswa UNPRI menyatakan bahwa cerita rakyat yang mereka ketahui tidak pernah didengar dari suku lain manapun. Cerita rakyat Nias tersebut yaitu :Legenda Mado-Mado Nias", Raja Yang Beristeri Dua, Famolaya, Siraso, Dewi Bibit Suku Nias, Eu Böwö, Baewa Si Faero, Legenda Awuwukha yang Perkasa, Anak Zamagawaulu dan aza-Gaza, 7 Anak Yang Dibuang, Burung Tua dan Burung Muda, Sazuzudanö, Lauwömaru, Futi Lölö Nafo, Tumbal Yang Menjadi batu.

Dua fokus penelitian di atas bermuara pada implikasi, antara lain a) metodologis yakni model teori dan analisis struktur naratif efektif dalam menelaah atau mengkaji struktur-struktur karya sastra yang bersifat fiksi seperti cerita rakyat, legenda, novel dan cerpen ataupun jenis sastra lisan lainnya. Analisis data dengan menggunakan analisis struktural naratif sangat membantu peneliti menelaah secara detail keterkaitan seluruh anasir karya sastra. Oleh karena itu, peneliti selanjutnya dapat menggunakan model ini apabila meneliti struktur-struktur karya sastra yang lain. Berdasarkan teknik analisis data yang dilakukan oleh peneliti dengan menggunakan model analisis struktur naratif, telah ditemukan bahwa ada 5 (lima) cerita rakyat yang tidak memiliki struktur waktu. Cerita rakyat yang tidak memiliki struktur waktu itu antara lain Famolaya, Siraso, Dewi Bibit Suku Nias, Legenda Awuwukha yang Perkasa, Burung Tua dan Burung Muda, Tumbal Yang Menjadi batu. Dengan demikian, penggunaan metode analisis ini sangat membantu peneliti melihat kekurangan struktur karya sastra. Oleh karena itu, hasil penelitian ini dapat dilanjutkan dengan tujuan mencari ataupun mengembangkan struktur-struktur cerita rakyat Nias yang belum lengkap dengan tetap berpedoman pada teori/model struktural naratif. b) Kebijakan yakni hasil penelitian menunjukkan ada 14 (empat belas) cerita rakyat Nias. Namun, informan (mahasiswa UNPRI Medan) menyatakan bahwa cerita rakyat Nias terancam punah karena berbagai faktor yang sangat kompleks salah satunya faktor perkembangan teknologi modern yang berpotensi sebagai ancaman bagi punahnya cerita rakyat Nias. Tantangannya ialah generasi muda zaman sekarang lebih tertarik dengan informasi-informasi yang bersifat modern/digital. Padahal cerita rakyat Nias 
dapat berfungsi sebagai tuntunan pendidikan atau sumber pembentukan karakter masyarakat dan memiliki nilai-nilai yang dapat dijadikan sebagai sumber norma dan etika. Oleh karena itu, demi tetap dilestarikannya cerita rakyat Nias, beberapa usaha yang perlu dilakukan yakni 1) Dinas Pendidikan dan Kebudayaan Kepulauan Nias dapat membuat kebijakan agar cerita rakyat dijadikan sebagai bahan ajar dalam buku-buku pelajaran Bahasa Indonesia di jenjang pendidikan sekolah menengah sampai sekolah menengah atas. Selain itu, perlu membukukan ataupun menerbitkan buku-buku khusus mengenai cerita rakyat Nias demi mencegah kepunahan cerita rakyat tersebut. 2) Semua pihak dapat berinisiatif untuk mengemas cerita rakyat ini menjadi animasi digital yang menarik yang dapat ditonton secara audio visual. c) Teoretis yakni hasil penelitian ini dapat berkontribusi untuk menguatkan teori yang dapat menambah wawasan pembaca dengan cara mempelajari teori-teori lain yang terkait dengan topik penelitian. Selama menganalisis data penelitian, peneliti menyadari bahwa ada keterkaitan hasil data dengan buku-buku/referensi yang digunakan. Oleh karena itu, hasil penelitian ini dapat digunakan untuk menguatkan baik teori tentang struktur karya sastra maupun teori mengenai nilai budaya (Nias).

\section{SIMPULAN}

Berdasarkan hasil penelitian, maka ada dua bagian yang menjadi simpulan yakni Pertama; cerita rakyat Nias memiliki struktur Naratif yang jelas yang bisa menjadi unsur pembangun suatu karya sastra. Struktur-struktur itu antara lain struktur plot, Fisik, Ras dan Relasi Gender, struktur ruang dan waktu dan terakhir struktur transmisi narasi. Kedua; Mahasiswa UNPRI memberikan pandangan-pandangan terhadap cerita rakyat Nias. secara ringkat pandangan tersebut dijelaskan berikut ini: 1) Mahasiswa UNPRI mengenal cerita rakyat sejak kecil dari orangtua mereka sendiri. Cerita rakyat Nias bermanfaat karena memiliki nilai moral, sosial, etika, nilai agama (religius) yang juga dapat berfungsi sebagai tuntunan-pendidikan. Oleh karena itu, cerita rakyat Nias perlu dilestarikan oleh semua pihak. 


\section{DAFTAR PUSTAKA}

Endraswara, Suwardi. 2011. Metodologi Penelitian Sastra-Epsitemologi, Model, Teori, Dan Aplikasi. Yogyakarta:CAPS

Faruk. 2012. Metode Penelitian Sastra-Sebuah Penjelajahan Awal. Yogyakarta: PustakaPelajar

Ghony, M. Djunaidi dan Fauzan Almanshur. 2012. Metodologi Penelitian Kualitatif. Yogyakarta: Ar-Ruzz Media.

La Ode Gusal. 2015. "Nilai-nilai Dalam Cerita Rakyat Sulawesi Tenggara Karya La Ode Sidu”. Dalam, Jurnal Humanika No 15 Vol 3.

Muhadjir, Noeng. 2011. Metodologi Penelitian. Edisi VI. Yogyakarta: Rake Serasin.

Moleong, Lexy. 2010. Metodologi Penelitian Kualitatif. Bandung: RosdaKarya.

Denzim, Norman K \& Yvona S. Lincoln. 2009. Handbook Of Qualitative Research. Yogyakarta: Pustaka Pelajar.

Ratna, N. K. 2015. Teori, Metode, Teknik Penelitian Sastra. Yogyakarta: Pustaka Pelajar.

Teeww, A. 2015. Sastra dan Ilmu Sastra. Bandung: PT Dunia Pustaka Jaya.

Universitas Amir Hamzah. 2008. Cerita dan Wacana Struktur Naratif dala Fiksi dan Film. Medan: Sumatera Utara. \{Teks Asli: Seymor Chattman, 1980. Story and Discourse, Narative Structure in Fiction and Film. Itacha and London: Cornell University Press 